\title{
Development of real-time PCR tests for the detection of Tenebrio molitor in food and feed
}

\section{Frédéric Debode, Aline Marien, Amaury Gerard, Frédéric Francis, Olivier Fumiere \& Gilbert Berben}

To cite this article: Frédéric Debode, Aline Marien, Amaury Gerard, Frédéric Francis, Olivier Fumiere \& Gilbert Berben (2017): Development of real-time PCR tests for the detection of Tenebrio molitor in food and feed, Food Additives \& Contaminants: Part A, DOI: 10.1080/19440049.2017.1320811

To link to this article: http://dx.doi.org/10.1080/19440049.2017.1320811

Accepted author version posted online: 21 Apr 2017

Submit your article to this journal $\sqrt{\top}$

View related articles $\longleftarrow$

View Crossmark data $\widetilde{\nearrow}$ 
Publisher: Taylor \& Francis \& Informa UK Limited, trading as Taylor \& Francis

Journal: Food Additives \& Contaminants: Part A

DOI: $10.1080 / 19440049.2017 .1320811$

\section{Development of real-time PCR tests for the detection of Tenebrio molitor in food and feed}

Debode Frédéric $^{1}$, Marien Aline ${ }^{1,2}$, Gérard Amaury ${ }^{1,3}$, Francis Frédéric ${ }^{3}$, Fumière Olivier ${ }^{1,2}$, and Berben Gilbert ${ }^{1,2}$

${ }^{1}$ Walloon Agricultural Research Center (CRA-W), Unit Traceability and Authentication, chaussée de Namur 24, 5030 Gembloux, Belgium; 'European Union Reference Laboratory for Animal Proteins in feedingstuffs (EURL-AP), Chaussée de Namur 24, 5030 Gembloux, Belgium; ${ }^{3}$ Functional and Evolutionary Entomology, Gembloux Agro-Bio Tech - University of Liège (ULg), Passage des Déportés 2, 5030 Gembloux, Belgium

Corresponding author email: f.debode@cra.wallonie.be

Keywords: insect, Tenebrio molitor, detection, real-time PCR

\section{Abstract}

Insects are rich in proteins and could be an alternative source of proteins to feed animals and humans. Numerous companies have started the production of insects for feed purposes. In Europe, these processed animal proteins are not yet authorized by legislation, as many questions still need to be answered concerning this "novel food". Authorizations will be possible when methods of authentication of the products are available. In this study we propose real-time PCR methods for the specific detection of the mealworm (Tenebrio molitor), one of the most widely used insects for food and feed production. Two PCR assays are proposed: a first one based on the wingless gene and a second one based on the cadherin gene. The PCR tests amplify fragments of $87 \mathrm{bp}$. These qualitative methods were tested according to several performance criteria. The specificity was tested on 34 insect species DNA but also on non-insect species including crustacean, mammals, birds and plants. The limit of detection was determined and was below 20 copies for the two PCR test. The applicability of the tests was demonstrated by the analysis of real-life processed samples containing Tenebrio molitor. 


\section{Introduction}

Europe has a deficit in protein production. More than 40 million tonnes of crop proteins are imported annually into EU countries (Häusling, 2011). The increase in the global population requires additional protein supplies from sustainable sources for inclusion in animal feed. Insects are rich in protein and can be reared on a wide range of substrates including valuable recycled proteins from organic waste and by-products of agriculture and the food industries (Ramos-Elorduy et al., 2002; Rumpold \& Schlüter, 2013). The insect species considered most suitable for feed production include silkworms, black soldier and the common house flies but also mealworms.

The protein percentage in the living mealworm (Tenebrio molitor) larvae has been evaluated between 18 and 27.6\% (Jones et al., 1972; Finke et al., 2002; Ghaly and Alkoaik, 2009; Siemianowska et al., 2013). This percentage doubles in dried ground larvae (Ng et al., 2001; Siemianowska et al., 2013; Han et al., 2016).

Commercial insect-rearing exists both outside and inside Europe. A growing number of companies are starting in Europe, but markets are limited by the current legislation, which does not yet permit the use of insects in livestock feed (Regulation EC 999/2001).

There are also several existing barriers to the use of insect proteins within feed, mainly due to the lack of data concerning the safety and nutritional qualities of insects. Moreover, insect-based products will not be allowed if characterization methods are not available. The identification of insect species in food and feed products is therefore an emerging application. DNA-based methods have generally been used for taxonomic classifications (Cook et al., 2002; Hebert et al., 2003a; Cameron, 2014; Mandal et al., 2014), forensic entomology (Dawnay et al.. 2007; Wells and Škaro, 2014 ; Malewski et al., 2010), predation (Hoogendoorn and Heimpel, 2001; Sheppard et al., 2005; Pons et al., 2006, Pons, 2006).

DNA barcoding (Hebert et al. 2003b; Jinbo et al., 2011; Yu et al., 2012) methods have been developed for species classification on the basis of the Cytochrome Oxidase I (COI) gene but require fragments of $600-800 \mathrm{bp}$. On the basis of the DNA barcodes corresponding to insect species and available in June 2009 (http://www.barcodinglife.org), Virgilio et al. (2010) estimated that the lack of reference DNA barcodes for $98 \%$ of the known insect species implied that insect DNA barcoding is subject to misidentification of queries without conspecifics in the database. However, detection of DNA in processed food or feed requires the use of small targets (Debode et al., 2007; Debode et al., 2017) and real-time PCR at present remains the technique of reference for this kind of application.

\section{Materials and methods}

\section{Samples}


Insects were collected in the environment or provided by the Functional and Evolutionary Entomology Unit of Gembloux Agro-Bio Tech (ULg, Gembloux, Belgium). Insects were selected in order to cover several taxonomic groups.

Real-life processed samples containing insects were bought in supermarkets, such as aperitif balls of Entomofood Conbuggie range (Deli Ostrich, Wingene, Belgium) containing 6 $\%$ of Tenebrio molitor or obtained from the IPIFF (International Producers of Insects for Food and Feed), such as industrial meals of $T$. molitor coming from different companies (confidential origin) producing insect meals.

\section{DNA extraction}

Genomic DNA was extracted and purified from all samples following the CTAB-based method described in Annex A.3.1 of the international standard ISO 21571 (2005). The quality and quantity of DNA extracted from samples were estimated spectrophotometrically using a Nanodrop ND-1000 spectrophotometer at $260 \mathrm{~nm}$ (A260) and $280 \mathrm{~nm}$ (A280) absorbance. DNA purity was determined using the A260/ A280 ratio. The amplifiability of the DNA extract was checked by real-time PCR with the $18 \mathrm{~S}$ targets for insects (this study), rbcL (Debode et al., 2012) for plants and GH ( $\mathrm{Li}$ et al., 2013) for salmon. Other species were tested with targets developed or evaluated in the framework of the EURL-AP (European Union Reference Laboratory for Animal Proteins in feedingstuff) activities (EURL-AP, 2013; EURLAP, 2014).

\section{Primers and probes}

Eurogentec (Seraing, Belgium) synthesized primers and probes. The probes were labeled with the reporter dye FAM ${ }^{\mathrm{TM}}$ at the 5'end, and the quencher dye TAMRA ${ }^{\mathrm{TM}}$ at the $3^{\prime}$ 'end. The primer and probe sequences developed for this study are presented in Table 1.

\section{Real-time PCR}

Real-time PCR reactions (total reaction volume of $25 \mu \mathrm{l}$ ) were performed on an Mx3005p (Agilent Technologies, Santa Clara, CA, USA) and an ABI7500 fast (Life Technologies, Foster City, CA) using Real-Time PCR Master Mix Diagenode (Universal Master Mix, GMOUN-A600, Seraing, Belgium), or Applied Biosystems (TaqMan® Universal Master Mix, 4324020). The reaction mixture included $12.5 \mu \mathrm{l}$ of Master Mix, $1.7 \mu \mathrm{l}$ of each primer $(5 \mu \mathrm{M})$, $1.5 \mu$ l of probe $(9 \mu \mathrm{M}), 2.6 \mu \mathrm{l}$ of doubly distilled water, and $5 \mu$ l of DNA. For PCRs using two probes (18S duplex PCR), the volume of water mentioned before was reduced by the volume of the second probe $(1.5 \mu \mathrm{l})$. Reaction mixtures were distributed on 96 -well reaction plates (Life Technologies) developed for the specific thermocyclers. Wells were covered with adhesive film, and centrifuged (500 rpm, 10 seconds) to eliminate any air bubbles in the well bottoms. PCR conditions were as follows: $2 \mathrm{~min}$ at $50^{\circ} \mathrm{C} ; 10 \mathrm{~min}$ at $95^{\circ} \mathrm{C} ; 50$ cycles of 15 seconds at $95^{\circ} \mathrm{C}$; and $1 \mathrm{~min}$ at $60^{\circ} \mathrm{C}$.

\section{Specificity testing}


The specificity of methods was checked on 34 insect species identified at ULg Gembloux Agro-Bio Tech including different taxonomic groups among which 11 Coleoptera (other than Tenebrio molitor), 7 Diptera, 5 Orthoptera, 2 Hemiptera, 3 Hymenoptera, 3 Lepidoptera, 1 Blattodea and 1 Dermaptera (Table 2). The specificity was also tested against 6 crustaceans, 1 mollusk, 6 mammals, 2 birds and 7 plant species (Table 2). 10 ng of DNA were used in the PCR reactions. Each DNA extract was tested in triplicate.

\section{Limit of detection (LOD) determination}

Target sensitivity was evaluated following the recommendations of the former AFNOR XP V03-020-2 standard (AFNOR 2008) (NB. this standard no longer exists, but the principles detailed in it are still valid). The absolute limit of detection (LOD) was determined for the PCR assay (primers + probe + amplification program) on dilutions of genomic material.

The subsequent dilutions had to contain approximately $50,20,10,5,2,1$, and 0.1 copies of the target. Six PCRs had to be achieved for each dilution. The method's LOD was the smallest copy number for which the six PCRs were positive, and only if PCR on the final dilution containing the 0.1 copy generated a maximum of one positive signal on the six replications. If more than one positive signal was observed for the 0.1 copy, the DNA quantities had to be revised. The highest acceptable absolute LOD required for a test was 20 copies.

\section{Dilutions}

Dilutions for LOD determination were conducted in water until an estimated target concentration of 20,000 copies $/ 5 \mu /$ had been reached. Further dilutions below this estimated copy number used a solution containing $5 \mathrm{ng} / \mathrm{\mu l}$ of salmon sperm DNA as background DNA. Low binding tubes were chosen to minimize DNA loss due to tube wall binding.

\section{Estimated number of haploid genomes}

The mean estimated DNA quantities necessary to obtain 20,000 target copies are based on data from the animal genome size database (www.genomesize.com) at the University of Guelph (Ontario, Canada). The DNA quantity corresponding to 20,000 target copies was estimated at $10.4 \mathrm{ng}$ for Tenebrio molitor.

\section{Results and discussion}

An attempt was first made to find targets enabling insect detection. Sequences were aligned for several candidate genes, including cytochrome oxidase I (Carapelli et al., 2000; Deagle et al., 2014; Porter et al., 2014), the wingless gene (Brower and DeSalle, 1998), the elongation factor 1a (Roger et al., 1999 ; Kim et al., 2010; Simon et al., 2010), the 28S RNA (Kjer, 2004; Hasegawa and Kasuya, 2006) and the 18S RNA (Hillis and Dixon, 2008). Phosphogluconate dehydrogenase gene and splicing factor $3 \mathrm{~B}$ subunit 1 were also investigated. 
Several problems were encountered with the different alignments. Firstly, low conservation rates of sequences were observed inside the taxonomic group of insects. Secondly, some interesting regions were AT-rich and the selection of primers and probes was not possible in accordance with the parameters advised by the Primer Express v3.0 software (Life Technologies, Foster City, CA) for efficient amplification. Thirdly, sequence data were not yet available at this stage. The availability of the sequences was highly variable as a function of the gene considered. Finally, similarities of sequences with unexpected organisms can be encountered for many insects.

Primers and probes were selected for the several cited targets but only the $18 \mathrm{~S}$ target gave interesting results. However the 18S PCR test was not functional on Diptera due to the probe. A second probe more specific to the Diptera order was then designed. The detection of insect species was then based on a couple of primers and two probes (one for the Diptera order and a second one for all the other insect orders) to be used in duplex.

For the specificity testing, the duplex target was able to detect DNA from the 34 tested insect species. No signal was obtained with the 16 other tested animal species (vertebrates and crustaceans). Unfortunately, once plant DNA was tested, signals were observed with tomato and wheat. The risk of false positive results was confirmed by an alignment with the 18S DNA sequence of wheat showing clear similarities for this 18S DNA fragment between insects and wheat. This problem of signal (albeit a late signal) was not solved by modification of the probe sequence even with shorter segments despite showing an acceptable Tm through use of the minor groove binder (Kutyavin et al., 2000), and is rather annoying as wheat is a product frequently found in food and feed products. This target was therefore used in this research as a way of checking that it was possible to amplify the DNA extracted from insects.

Due to these problems with a general insect PCR test, we then focused on tests for well-defined insect species and more specifically for Tenebrio molitor. Two targets were proposed for the detection of Tenebrio molitor. The first one was based on the wingless gene and did not show aspecificities with the non-target DNA tested.

The second one was based on the cadherin gene. Among the 34 tested insect species, the cadherin target showed positive a signal with Zophobas morio F. (also called the superworm or giant mealworm). Late signals ( $\mathrm{Cq}>40)$ were observed with Bombyx mori $L$. (the silkworm). Among the non-insect species, a late signal ( $\mathrm{Cq}>40)$ was observed with the crustacean Gammarus sp. Results are presented in Table 2. Positive signals were obtained on processed samples known to contain $T$. molitor showing the applicability of the wingless and cadherin targets on real-life samples (Table 3 ).

The limit of detection of these two targets was estimated at 20 copies (10.4 pg of DNA from Tenebrio molitor) for the wingless target and 10 copies for the cadherin target, 
using the AFNOR XP V03-020-2 standard approach. The two targets therefore reach the recommended performance criteria ( $\leq 20$ copies).

In conclusion, a global target for the detection of insect in food and feed product still needs to be found. The $18 \mathrm{~S}$ target proposed in this work is interesting but suffers from aspecificities with some important plant species. However, the $18 \mathrm{~S}$ target can be used as a control to show that the DNA obtained from insect is amplifiable.

This paper proposes two candidate genes for the qualitative detection of Tenebrio molitor. The targets are based on the wingless and cadherin genes. These PCR tests were fit for purpose in terms of specificity, sensitivity and applicability.

\section{Acknowledgements}

We are grateful to Denis Roulez, Cécile Ancion, Gaëlle Antoine, Julien Maljean (GMO team of CRA-W) and to Loic Mariscal Diaz (Student Helha, Fleurus, Belgium) for their technical help. We also thanks IPIFF for the industrial meals provided.

\section{Competing interests}

The authors declare that they have no competing interests.

\section{References}

AFNOR XP-V-03-020-2. 2008. Détection et quantification des organismes végétaux génétiquement modifiés et produits dérivés. Partie 2: Méthodes basées sur la réaction de polymérisation en chaîne. Association Française de Normalisation, Saint-Denis La Plaine, France.

Brower A V Z, DeSalle R. 1998. Patterns of mitochondrial versus nuclear DNA sequence divergence among nymphalid butterflies: the utility of wingless as a source of characters for phylogenetic inference. Insect Molecular Biology 7:73-82.

Cameron S L. 2014. Insect mitochondrial genomics: implications for evolution and phylogeny. Annual Review of Entomology 59:95-117.

Carapelli A, Frati F, Nardi F, Dallai R, Simon C. 2000. Molecular phylogeny of the apterygotan insects based on nuclear and mitochondrial genes. Pedobiologia 44 :361-373. 
Cook L G, Gullan P J, Trueman H E. 2002. A preliminary phylogeny of the scale insects (Hemiptera: Sternorrhyncha: Coccoidea) based on nuclear small-subunit ribosomal DNA. Molecular Phylogenetics and Evolution 25:43-52.

Dawnay N, Ogden R, McEwing R, Carvalho G R, Thorpe R S. 2007. Validation of the barcoding gene $\mathrm{COI}$ for use in forensic genetic species identification. Forensic Science International 173:1-6.

Deagle B E, Jarman S N, Coissac E, Pompanon F, Taberlet P. 2014. DNA metabarcoding and the cytochrome $\mathrm{C}$ oxidase subunit I marker: not a perfect match. Biology letters $10: 20140562$.

Debode F, Janssen E, Berben G. 2007. Physical degradation of genomic DNA of soybean flours does not impair relative quantification of its transgenic content. European Food Research and Technology 226:273-280.

Debode F, Janssen E, Marien A, Berben G. 2012. DNA detection by conventional and realtime PCR after extraction from vegetable oils. Journal of the American Oil Chemists' Society 89:1249-1257.

Debode F, Marien A, Janssen E, Bragard C, Berben G. 2017. The influence of amplicon length on real-time PCR results. Biotechnologie, Agronomie, Société et Environnement $21: 3-11$

EURL-AP Standard Operating Procedure. 2014. Detection of ruminant DNA in feed using real-time PCR. http://eurl.craw.eu/img/page/sops/EURLAP\%20SOP\%20Ruminant\%20PCR\%20V1.1.pdf

EURL-AP Standard Operating Procedure. 2013. Detection of horse DNA using real-time PCR.

http://eurl.craw.eu/img/page/sops/Protocol\%20for\%20detection\%20of\%20horse\%20DNA\%2 Ousing\%20real-time\%20PCR.pdf

Finke M D. 2002. Complete nutrient composition of commercially raised invertebrates used as food for insectivores. Zoo Biology 21:269-285. 
Ghaly A E, Alkoaik F N. 2009. The yellow mealworm as a novel source of protein. American Journal of Agricultural and Biological Sciences 4:319-331.

Han S R, Lee B S, Jung K J, Yu H J, Yun E Y, Hwang J S, Moon K S. 2016. Safety assessment of freeze-dried powdered Tenebrio molitor larvae (yellow mealworm) as novel food source: Evaluation of 90-day toxicity in Sprague-Dawley rats. Regulatory Toxicology and Pharmacology 77:206-212.

Hasegawa E, Kasuya E. 2006. Phylogenetic analysis of the insect order Odonata using 28S and 16S rDNA sequences: a comparison between data sets with different evolutionary rates. Entomological Science 9:55-66.

Häusling M. 2011. Report: The EU protein deficit: what solution for a long-standing problem? European Parliament. Committee on Agriculture and Rural Development. A7-0026/2011, Brussels, Belgium.

Hebert P D, Ratnasingham S, de Waard J R. 2003a. Barcoding animal life: cytochrome c oxidase subunit 1 divergences among closely related species. Proceedings of the Royal Society of London B: Biological Sciences 270:S96-S99.

Hebert P D, Cywinska A, Ball S L. 2003b. Biological identifications through DNA barcodes. Proceedings of the Royal Society of London B: Biological Sciences 270:313-321.

Hillis D M, Dixon M T. 1991. Ribosomal DNA: molecular evolution and phylogenetic inference. Quarterly Review of Biology 411-453.

Hoogendoorn M, Heimpel G E. 2001. PCR-based gut content analysis of insect predators: using ribosomal ITS-1 fragments from prey to estimate predation frequency. Molecular Ecology, 10:2059-2067.

ISO 21571. 2005. Foodstuffs - Methods of analysis for the detection of genetically modified organisms and derived products - Nucleic acid extraction. International Organisation for Standardization, Geneva, Switzerland.

Jinbo U, Kato T, Ito M. 2011. Current progress in DNA barcoding and future implications for entomology. Entomological Science 14 :107-124. 
Jones L D, Cooper R W, Harding R S. 1972. Composition of mealworm Tenebrio molitor larvae. The Journal of Zoo Animal Medicine 3:34-41.

Kim M I, Wan X, Kim M J, Jeong H C, Ahn N H, Kim K G, Han Y S, Kim I. 2010. Phylogenetic relationships of true butterflies (Lepidoptera: Papilionoidea) inferred from COI, 16S rRNA and EF-1a sequences. Molecules and Cells $30: 409-425$.

Kjer K M. 2004. Aligned 18S and insect phylogeny. Systematic Biology 53:506-514.

Kutyavin I V, Afonina I A, Mills A, Gorn V V, Lukhtanov E A, Belousov E S, Singer M J, Walburger D K, Lokhov S G, Gall A A., Dempcy R, Reed M W, Meyer R B, Hedgpeth J. 2000. 3'-minor groove binder-DNA probes increase sequence specificity at PCR extension temperatures. Nucleic Acids Research 28:655-661.

Li X, Li J, Zhang S, He Y, Pan L. 2013. Novel real-time PCR method based on growth hormone gene for identification of Salmonidae ingredient in food. Journal of Agriculture and Food Chemistry 61:5170-5177

Malewski T, Draber-Mońko A, Pomorski J, Łoś M, Bogdanowicz W. 2010. Identification of forensically important blowfly species (Diptera: Calliphoridae) by high-resolution melting PCR analysis. International Journal of Legal medicine 124:277-285.

Mandal S D, Chhakchhuak L, Gurusubramanian G, Kumar N S. 2014. Mitochondrial markers for identification and phylogenetic studies in insects-A Review. DNA Barcodes 2.

Ng W K, Liew F L, Ang L P, Wong K W. 2001. Potential of mealworm (Tenebrio molitor) as an alternative protein source in practical diets for African catfish, Clarias gariepinus. Aquaculture Research 32:273-280.

Pons J, Barraclough T G, Gomez-Zurita J, Cardoso A, Duran D P, Hazell S, Kamoun S, Sumlin W D, Vogler A. P. 2006. Sequence-based species delimitation for the DNA taxonomy of undescribed insects. Systematic Biology 55:595-609.

Pons J. 2006. DNA-based identification of preys from non-destructive, total DNA extractions of predators using arthropod universal primers. Molecular Ecology Notes 6:623-626. 
Porter T M, Gibson J F, Shokralla S, Baird D J, Golding G B, Hajibabaei M. 2014. Rapid and accurate taxonomic classification of insect (class Insecta) cytochrome c oxidase subunit 1 (COI) DNA barcode sequences using a naïve Bayesian classifier. Molecular Ecology Resources 14:929-942.

Ramos-Elorduy J, González E A., Hernández A R, Pino J M. 2002. Use of Tenebrio molitor (Coleoptera: Tenebrionidae) to recycle organic wastes and as feed for broiler chickens. Journal of Economic Entomology 95:214-220.

Roger A J, Sandblom O, Doolittle W F, Philippe H. 1999. An evaluation of elongation factor 1 alpha as a phylogenetic marker for eukaryotes. Molecular Biology and Evolution 16:218-233.

Rumpold B A, Schlüter O K. 2013. Nutritional composition and safety aspects of edible insects. Molecular Nutrition \& Food Research 57:802-823.

Siemianowska E, Kosewska A, Aljewicz M, Skibniewska K A, Polak-Juszczak L, Jarocki A, Jedras M. 2013. Larvae of mealworm (Tenebrio molitor L.) as European novel food. Agricultural Sciences 4:287.

Sheppard S K, Bell J, Sunderland K D, Fenlon J, Skervin D, Symondson W O C. 2005. Detection of secondary predation by PCR analyses of the gut contents of invertebrate generalist predators. Molecular Ecology 14:4461-4468.

Simon S, Schierwater B, Hadrys H. 2010. On the value of Elongation factor-1a for reconstructing pterygote insect phylogeny. Molecular Phylogenetics and Evolution 54:651656.

Virgilio M, Backeljau T, Nevado B, De Meyer M. 2010. Comparative performances of DNA barcoding across insect orders. BMC Bioinformatics 11:1.

Wells J D, Škaro V. 2014. Application of DNA-Based Methods in Forensic Entomology. Forensic DNA Applications: An Interdisciplinary Perspective 353. ISBN: 978-14665-8022-0.

Yu D W, Ji Y, Emerson B C, Wang X, Ye C, Yang C, Ding Z. 2012. Biodiversity soup: metabarcoding of arthropods for rapid biodiversity assessment and biomonitoring. Methods in Ecology and Evolution 3:613-623. 


\section{List of Tables}

Table I. Primers and probes used for the detection of insects DNA

Table II. 18S-insect, wingless and cadherin PCR tests on animal and plant species $(n=3)$

Table III. 18S-Insect, wingless and cadherin PCR tests on processed samples known to contain Tenebrio molitor 
Table I. Primers and probes used for the detection of insect DNA

\begin{tabular}{|c|c|c|c|}
\hline Target & Name & Sequences 5'-3' & $\begin{array}{c}\text { Amplicon } \\
\text { size (bp) }\end{array}$ \\
\hline \multirow{4}{*}{ Insects } & 18s-INS-2F & GCGACGGATCTTTCAAATGTC & \multirow{4}{*}{81} \\
\hline & 18s-INS-R & CCCCGTTACCCGTTACAACC & \\
\hline & 18s-INS-P & FAM- CTTATCAACTGTCGATGGTAGGTTCTGCGC -TAMRA & \\
\hline & 18s-INS-DIP-P & FAM- TAGTCCIAGATACTACCATCAAIAGTTGATAGGGC -TAMRA & \\
\hline \multirow{3}{*}{$\begin{array}{l}\text { Tenebrio } \\
\text { molitor }\end{array}$} & TM-WING-F & CAGGGTTGAACGGGTTCAGT & \multirow{3}{*}{87} \\
\hline & TM-WING-R & ATACTATTTCGGGCAACAGCATC & \\
\hline & TM-WING-P & FAM -AAGCCGTACTTGTGTTACGGCGGTTCAC-TAMRA & \\
\hline \multirow{3}{*}{$\begin{array}{l}\text { Tenebrio } \\
\text { molitor }\end{array}$} & Cadherin-2F & AATAGACGAAGACAACCAGCTTGA & \multirow{3}{*}{87} \\
\hline & Cadherin-2R & TCTCTATCGGCATCACTATATGTTAGATT & \\
\hline & Cadherin-2P & FAM - CCGGACGACACCCTCAACGGA-TAMRA & \\
\hline
\end{tabular}

Note: $1=$ Inosine

Table II. 18S-insect, wingless and cadherin PCR tests on animal and plant species $(n=3)$

\begin{tabular}{|c|c|c|c|c|c|c|}
\hline \multirow{2}{*}{\multicolumn{2}{|c|}{ Taxonomic classification }} & \multirow{3}{*}{$\begin{array}{l}\text { Latin name or order } \\
\text { Hermetia illucens L. }\end{array}$} & \multirow{3}{*}{$\begin{array}{l}\text { Common name } \\
\text { Black soldier fly }\end{array}$} & \multicolumn{3}{|c|}{ Targets } \\
\hline & & & & 18S- Insect & Wingless & Cadherin \\
\hline \multirow{23}{*}{$\begin{array}{l}\mathrm{I} \\
\mathrm{N} \\
\mathrm{S} \\
\mathrm{E} \\
\mathrm{C} \\
\mathrm{T} \\
\mathrm{S}\end{array}$} & \multirow{7}{*}{ Diptera } & & & + & - & - \\
\hline & & Tabanus sp. & Horsefly & + & - & - \\
\hline & & Bibio marci L. & St.Mark's fly & + & - & - \\
\hline & & Calliphora vicina R.- D. & Blow fly & + & - & - \\
\hline & & Sarcophaga carnaria $L$. & Common fresh fly & + & - & - \\
\hline & & Bombylius major $L$. & Large bee-fly & + & - & - \\
\hline & & Chironomus plumosus $L$. & Buzzer midge & + & - & - \\
\hline & \multirow{5}{*}{ Orthoptera } & Locusta migratoria L. & Migratory locust & + & - & - \\
\hline & & Acheta domesticus $L$. & House cricket & + & - & - \\
\hline & & Gryllus bimaculatus De G. & $\begin{array}{l}\text { Mediterranean field } \\
\text { cricket }\end{array}$ & + & - & - \\
\hline & & Gryllus assimilis $F$. & Jamaican field cricket & + & - & - \\
\hline & & Gryllus sp. & Cricket & + & - & - \\
\hline & \multirow{11}{*}{ Coleoptera } & Pachnoda sp. & Dola's worm & + & - & - \\
\hline & & Tenebrio molitor $L$. & Mealworm & + & + & + \\
\hline & & Zophobas morio $F$. & Superworm & + & - & + \\
\hline & & Alphitobius diaperinus $P$. & Lesser mealworm & + & - & - \\
\hline & & Oxythyrea funesta $P$. & White-spotted rose beetle & + & - & - \\
\hline & & Melolontha melolontha L. & Cockchafer & + & - & - \\
\hline & & Leptinotarsa decemlineata S. & Colorado potato beetle & + & - & - \\
\hline & & Cassida viridis $L$. & Green tortoise beetle & + & - & - \\
\hline & & Cicindela campestris $L$. & Green tiger beetle & + & - & - \\
\hline & & Nicrophorus humator G. & Black sexton beetle & + & - & - \\
\hline & & Nicrophorus vespillo $L$. & Common burying beetle & + & - & - \\
\hline
\end{tabular}




\begin{tabular}{|c|c|c|c|c|c|}
\hline & Cetonia aurata $L$. & Rose chafer & + & - & - \\
\hline \multirow{2}{*}{ Hemiptera } & Pyrrhocorus apterus $L$. & Firebug & + & - & - \\
\hline & Psyllus sp. & Jumping plant louse & + & - & - \\
\hline \multirow{3}{*}{ Hymenoptera } & Componotus sp. & Carpenter ant & + & - & - \\
\hline & Vespa sp. & Hornet & + & - & - \\
\hline & Vespula sp. & Wasp & + & - & - \\
\hline \multirow{3}{*}{ Lepidoptera } & Biston betularia $L$. & Peppered moth & + & - & - \\
\hline & Tineola sp. & Moth & + & - & - \\
\hline & Bombyx mori $L$. & Silkworm & + & - & $+(\mathrm{Cq}>40)$ \\
\hline Blattodea & Blatta orientalis $L$. & Oriental cockroach & + & - & - \\
\hline Dermaptera & Forficula auricularia $L$. & Common earwing & + & - & - \\
\hline \multirow{6}{*}{ Crustacean } & Euphausia superba $D$. & Antartic krill & - & - & - \\
\hline & Penaeus vannamei $B$. & Whiteleg shrimp & - & - & - \\
\hline & Nephrops norvegicus $L$. & Langoustine & - & - & - \\
\hline & Homarus gammarus $L$. & European lobster & - & - & - \\
\hline & Paralithodes camtschatieus $T$. & Red king crab & - & - & - \\
\hline & Gammarus sp. & Scuds & - & - & $+(\mathrm{Cq}>40)$ \\
\hline Mollusca & Teuthida sp. & Squid & - & - & - \\
\hline \multirow{6}{*}{ Mammals } & Bos taurus $L$. & Beef & - & - & - \\
\hline & Sus scrofa $L$. & Pork & - & - & - \\
\hline & Ovis aries $L$. & Sheep & - & - & - \\
\hline & Equus caballus $L$. & Horse & - & - & - \\
\hline & Equus asinus $L$. & Donckey & - & - & - \\
\hline & Homo sapiens $L$. & Human & - & - & - \\
\hline Fish & Salmo salar L. & Salmon & - & - & - \\
\hline \multirow{2}{*}{ Birds } & Gallus gallus $L$. & Chicken & - & - & - \\
\hline & Meleagris gallopavo L. & Turkey & - & - & - \\
\hline \multirow{7}{*}{ Plants } & Glycine max $M$. & Soybean & - & - & - \\
\hline & Zea mays $L$. & Maize & $+(\mathrm{Cq}>37)$ & - & - \\
\hline & Brassica rapa $L$. & Rapeseed & $+/-$ & - & - \\
\hline & Triticum aestivum $L$. & Wheat & + & - & - \\
\hline & Oryza sativa L. & Rice & - & - & - \\
\hline & Solanum lycopersicum L. & Tomato & + & - & - \\
\hline & Beta vulgaris $L$. & Sugar beet & - & - & - \\
\hline
\end{tabular}

+: positive signal, - : negative signal, +/- : signals obtained with some samples but not all, $\mathrm{Cq}>37$ : indicative value corresponding to a late signal 
Table III. 18S-Insect, wingless and cadherin PCR tests on processed samples known to contain Tenebrio molitor

\begin{tabular}{|c|c|c|c|}
\hline \multirow{2}{*}{ Commercial product } & \multicolumn{3}{|c|}{ Targets } \\
\cline { 2 - 4 } & 18S- Insect & Wingless & Cadherin \\
\hline Aperitif balls & + & + & + \\
\hline Industrial meal 1 & + & + & + \\
\hline Industrial meal 2 & + & + & + \\
\hline
\end{tabular}

